\title{
Role of Fcy receptors in the activation of neutrophils by soluble and insoluble immunoglobulin aggregates isolated from the synovial fluid of patients with rheumatoid arthritis
}

\author{
John J Robinson, Fiona Watson, Roger C Bucknall, Steven W Edwards
}

\begin{abstract}
Objectives-Synovial fluid from patients with rheumatoid arthritis contains both soluble and insoluble immunoglobulin aggregates which activate reactive oxidant production in human neutrophils. The objectives were to determine the roles played by $\mathrm{Fc} \gamma$ receptors in activation of neutrophils by these complexes.

Methods-Pronase treatment was used to remove FcyRIII from the neutrophil surface and blocking monoclonal antibodies were used to prevent the binding of complexes to FcyRII and FcyRIII.

Results-When Fc $\gamma$ RIII was removed from the cell surface by pronase treatment, activation by the soluble aggregates did not occur [mean (SD) inhibition $89(16) \%, \quad n=6]$ whereas activation via the insoluble aggregates was less affected [34 $(16) \%, n=6]$. Blocking the binding to FcyRIII with antibodies decreased activation in response to the soluble aggregates [mean (SD) inhibition $71(22) \%, n=8$ ] but again had a lower effect on activation by the insoluble aggregates [40 $(17) \%, n=9]$. When binding to FcyRII was blocked, activation via the soluble aggregates was substantially inhibited [mean (SD) $93(13) \%, n=8$ ] whereas that via the insoluble aggregates was inhibited to a much lesser extent [ 28 $(38) \%, \mathbf{n}=9$ ]. When Fc $\gamma$ RII and III were simultaneously blocked, activation by the insoluble aggregates was only inhibited by $45 \%[(19), n=5]$.

Conclusion-These data thus indicate that activation of human neutrophils by soluble immunoglobulin aggregates from rheumatoid synovial fluid occurs via cooperative occupancy of both FcyRII and III: perturbation of binding to either of these receptor classes will abrogate activation.
\end{abstract}

(Ann Rheum Dis 1994; 53: 515-520)

In addition to their crucial role in host defence, it is appreciated that inappropriate infiltration and activation of neutrophils into tissues can result in tissue damage in inflammatory conditions such as rheumatoid arthritis. Much evidence now exists in previous reports to suggest that neutrophil activation has occurred within synovial joints ${ }^{1.7}$ and hence it is of potential pharmacological interest to understand the molecular processes which activate and regulate neutrophil function within such diseased joints. The major neutrophilactivating factors within synovial fluid appear to be immune complexes/immunoglobulin aggregates $^{8-12}$ which are capable of activating neutrophils via interactions with their plasma membrane $\mathrm{Fc}$ receptors.

Neutrophils possess receptors recognising the Fc portions of IgG and IgA ${ }^{13}{ }^{14}$ and of these the $\mathrm{Fc} \gamma$ receptors are the most clearly defined. Three types of Fc $\gamma R$ can be present. ${ }^{15}$ Fc $\gamma$ RI (CD64) is not present on blood neutrophils but its expression is up-regulated upon exposure to cytokines such as $\gamma$-interferon ${ }^{16}$; this receptor is also detected at low levels on neutrophils isolated from the synovial fluid of some patients with rheumatoid arthritis. ${ }^{5}$ Fc $\gamma$ RII (CD32) and Fc $\gamma$ RIII (CD16) are both present on the surface of blood neutrophils at levels of about 7-15000 and 100-200 000 per cell, respectively. ${ }^{17}$ There is much debate as to the role of FcyRII and FcyRIII in neutrophil function. Neither of these bind monomeric IgG, but they bind dimers, trimers, immune complexes and opsonised particles. It is currently believed that FcyRIII binds complexes, but this binding does not activate phagocytosis, degranulation or the respiratory burst: Fc $\gamma$ RII occupancy, however, is believed to result in neutrophil activation. ${ }^{18}{ }^{19}$ Unlike Fc $\gamma$ RII, Fc $\gamma$ RIII is held on the neutrophil plasma membrane via a glycerophosphoinositol anchor which is cleaved upon activation, ${ }^{20}$ and may also be released experimentally via treatment of neutrophils with pronase, elastase and phospholipase C.

We have recently shown that synovial fluid from patients with rheumatoid arthritis contains both soluble and insoluble immunoglobulin aggregates which are capable of activating reactive oxidant production by neutrophils. ${ }^{9}$ However, several lines of evidence indicate that these aggregates activate neutrophils via distinct mechanisms. Firstly, the soluble aggregates only activate neutrophils that have been primed in vivo or in vitro by GM-CSF or $\gamma$-interferon. Secondly, the soluble aggregates activate a transient (2-4 minutes) burst of oxidase function in primed cells whereas the insoluble aggregates stimulate a slower (15-20 minutes) activation in primed 
or unprimed cells. Thirdly, activation via the soluble aggregates is staurosporine-insensitive (and hence probably protein kinase Cinsensitive), whereas that activated by the insoluble aggregates is staurosporine-sensitive. ${ }^{21}$ Thus these observations indicate that the soluble and insoluble aggregates activate neutrophils via processes which differ in their receptor/signal transduction pathways. The aim of this work therefore was to determine the roles of FcyRII and FcyRIII in neutrophil activation via these immunoglobulin aggregates isolated from the synovial fluid of patients with rheumatoid arthritis.

\section{Materials and methods \\ PREPARATION OF NEUTROPHILS}

Neutrophils were isolated from heparinised venous blood of healthy volunteers using Mono Poly-resolving Medium exactly as described in the manufacturers instructions. ${ }^{22}$ The process involved the separation of neutrophils via density gradient centrifugation at $600 \mathrm{~g}$ for 25 minutes. The neutrophil band was removed and subjected to hypotonic lysis to eliminate contaminating erythrocytes. After purification, neutrophils were washed and resuspended in RPMI 1640 medium (containing $20 \mathrm{mM}$ HEPES) and their purity $(>97 \%)$ and viability ( $>95 \%)$ assessed by MayGrünwald/Giemsa staining and trypan blue exclusion, respectively. Cells were counted using a Fuchs-Rosenthal haemocytometer slide after a 100 fold dilution, and used within 5 hours of preparation.

PREPARATION OF SYNOVIAL FLUID

Synovial fluid was collected by aspiration of joints from rheumatoid arthritis patients with knee effusions and collected into heparinised tubes. The fluid was then centrifuged at $600 \mathrm{~g}$ for 10 minutes to remove the infiltrated cells. The cell free fluid was then either used immediately or else stored in aliquots at $-20^{\circ} \mathrm{C}$, before fractionation by centrifugation at $11600 \mathrm{~g}$ for 2 minutes. ${ }^{9}$ The resultant supernatant was retained whilst the pellet was resuspended to an equivalent volume in RPMI 1640 medium. In all, synovial fluid samples from 9 different patients with seropositive rheumatoid arthritis were examined.

NEUTROPHIL PRIMING

Suspensions of neutrophils were incubated for 1 hour at $37^{\circ} \mathrm{C}$ in $\mathrm{RPMI} 1640$ medium at $10^{7}$ cells $/ \mathrm{ml}$. Control suspensions contained no further additions whilst primed neutrophils were supplemented with $50 \mathrm{U} / \mathrm{ml}$ recombinant (r) GM-CSF. ${ }^{23}$ After incubation under these conditions the ability of the cells to generate reactive oxidants was assessed.

\section{MEASUREMENT OF REACTIVE OXIDANT} GENERATION

Chemiluminescence was performed on suspensions of neutrophils $\left(5 \times 10^{5} / \mathrm{ml}\right)$ suspended in RPMI 1640 medium containing $10 \mu \mathrm{M}$ luminol in a total volume of $1 \mathrm{ml}$, at $37^{\circ} \mathrm{C} .{ }^{24}$ After the addition of stimuli, photon emission was measured at $37^{\circ} \mathrm{C}$ using either a 25 channel LKB Wallac 1251 luminometer or else a single channel LKB 1250 luminometer.

ANALYSIS OF NEUTROPHIL MEMBRANE

RECEPTOR EXPRESSION

The monoclonal antibodies used were IV3 (anti-CD32, from Mederex) and Leu $11 \mathrm{~b}$ (anti-CD16, from Becton Dickinson) which recognise the intermediate and low affinity receptors respectively, of the Fc portion of IgG (that is, FcyRII and FcyRIII). $31 \mathrm{D} 8$ was a gift from Dr Krause, Hartford Hospital, Connecticut, USA: $31 \mathrm{D} 8$ positive cells avidly bind formylpeptides, whereas $31 \mathrm{D} 8$ negative cells do not respond functionally to fMet-LeuPhe. ${ }^{2526}$ For immunostaining of isolated neutrophils, ${ }^{27}$ cells were suspended in PBS/ $1 \%$ BSA (globulin-free) $/ 0 \cdot 1 \%$ sodium azide, $\mathrm{pH} 7 \cdot 2$, and receptor expression measured using a standard indirect immunofluorescence technique using FITC-labelled goat-(antimouse) immunoglobulin as a second layer. Both first and second layer antibodies were added at saturating concentrations, and in all experiments non-immune mouse IgG of the appropriate isotype was included as a class specific first layer control. Stained cells were fixed in $1 \%$ paraformaldehyde in PBS and analysed using a Becton Dickinson FACS Analyser 1 and a Consort 30 computer and software. Fluorescence distributions represent a total of 5000 gated events (cells), with the mean fluorescence proportional to the number of specific antigenic sites per cell.

PRONASE TREATMENT

Suspensions of primed neutrophils $\left(1 \times 10^{7}\right)$ were incubated in the presence of $50 \mu \mathrm{g} / \mathrm{ml}$ pronase for 30 minutes at $37^{\circ} \mathrm{C}$, to cleave GPIlinked membrane receptors. Cells were primed in order to mobilise sub-cellular pools of receptors on to the plasma membrane before addition of pronase. Membrane receptor expression was subsequently analysed by immunostaining and chemiluminescence determined as described above.

MONOCLONAL ANTIBODY BLOCKING STUDIES Monoclonal antibodies 197 (anti-FcyRI/ CD64, Mederex), IV3 (anti-Fc $\gamma$ RII/CD32, Mederex) and Leu 11b (anti-FcyRIII/CD16, Becton Dickinson) were used at saturating concentrations $(2.5 \mu \mathrm{g} / \mathrm{ml})$, after the preservative azide was removed by washing with PBS through Millipore $30 \mathrm{kDa}$ filters (Ultrafree-MC filter unit, low-binding PLTK membrane). Antibodies were added to neutrophil suspensions $\left(2 \times 10^{6} / \mathrm{ml}\right)$ and incubated for 10 minutes at $37^{\circ} \mathrm{C}$ prior to addition of rheumatoid immune complexes and analysis of chemiluminescence. 


\section{Results}

THE EFFECT OF PRONASE TREATMENT ON NEUTROPHIL MEMBRANE EXPRESSION AND FUNCTION

When primed neutrophils were treated with pronase $(50 \mu \mathrm{g} / \mathrm{ml}$ for 30 minutes) their membrane expression of 31D8 and Fc $\gamma$ RIII was considerably decreased (fig 1) compared with cells incubated in the absence of the enzyme [mean (SD) decrease in expression $=89 \%(2), n=3$, and $76 \%$ (3), $n=3$, for $31 \mathrm{D} 8$ and FcyRIII respectively). However, pronase treatment did not significantly affect Fc $\gamma$ RII or CD11b receptor expression (mean (SD) decrease in expression $=0.7 \%(0.6)$, $n=3$, and $9 \%(8), n=3$, for $F c \gamma R I I$ and $\mathrm{CD} 11 \mathrm{~b}$ respectively). Thus, pronase treatment cleaved FcyRIII and the receptor recognised by monoclonal antibody 31D8 (which are GPI-linked), without markedly affecting Fc $\gamma$ RII or CD11b (which are attached to the plasma membrane via a hydrophobic transmembrane anchor).

When primed neutrophils were incubated with pronase and then stimulated with fMetLeu-Phe (fig 2A), the chemiluminescence response was inhibited by $60 \%$ (mean (SD) inhibition $=62 \%(13), n=6)$ compared with responses of cells incubated in the absence of pronase. PMA stimulation of oxidant production was not markedly affected by pronase treatment (mean (SD) inhibition $=16 \%(7)$, $\mathrm{n}=5$, fig 2B) as was expected because PMA activates protein kinase $C$ and does not utilise a plasma membrane receptor. The precise receptor recognised by monoclonal antibody $31 \mathrm{D} 8$ is not certain but previous work has clearly shown that 31D8-positive cells are
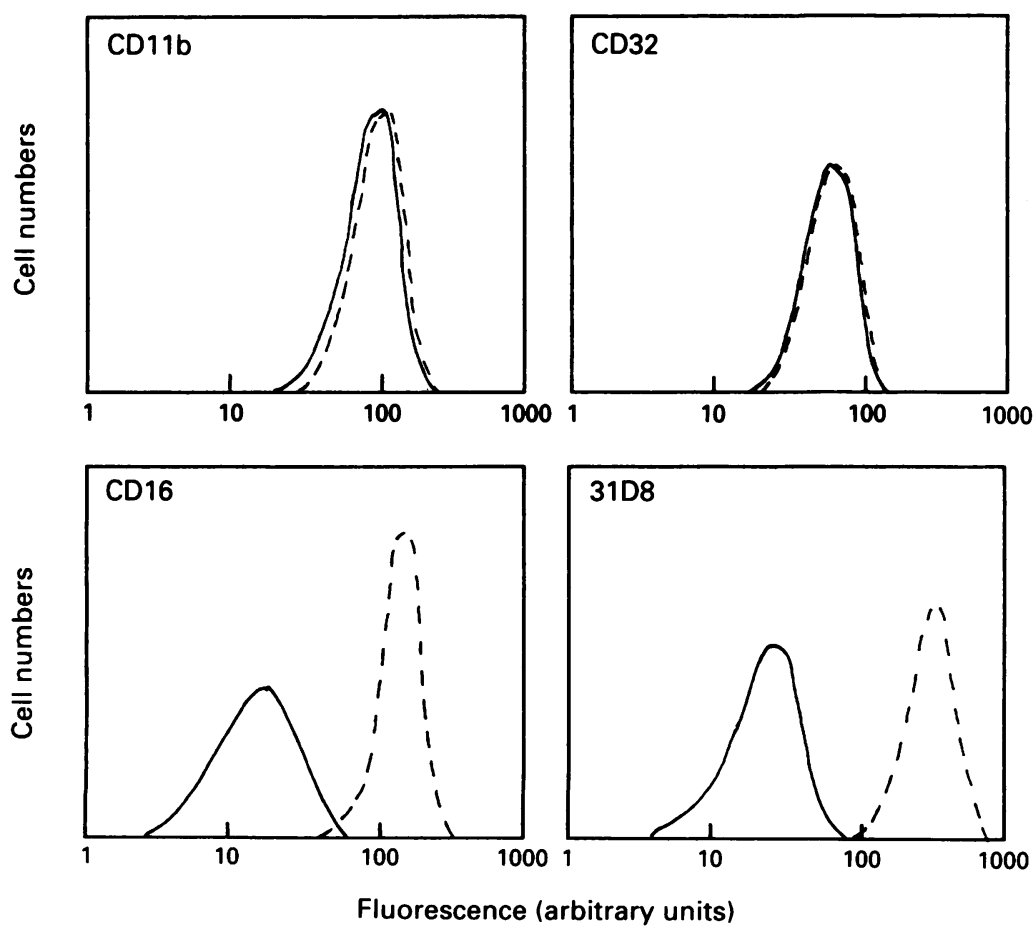

Figure 1 Plasma membrane receptor expression after pronase treatment. Control bloodstream neutrophils in RPMI $\left(10^{7} \mathrm{cells} / \mathrm{ml}\right)$ were incubated for 1 hour at $37^{\circ} \mathrm{C}$ in the presence of GM-CSF (50 U/ml) Cells were then further incubated in the presence or absence of pronase $(50 \mu \mathrm{g} / \mathrm{ml})$ for 30 minutes at $37^{\circ} \mathrm{C}$. Receptor expression (CD32, CD16, $31 \mathrm{D} 8$ and $C D 11 b$ ) was quantified by immunostaining (-- Primed, - Pronase treatment). Similar results were found in at least five further experiments.
fMet-Leu-Phe responsive, whereas 31D8negative cells are not. ${ }^{25} 26$

We have previously shown that rheumatoid synovial fluid contains soluble and insoluble IgG-containing immune complexes. ${ }^{9}$ Protein A affinity chromatography removes both types of complex and the flow through from this column does not activate the respiratory burst of neutrophils. This treatment thus removes all respiratory burst activating factors from synovial fluid and hence these two types of complex are the only factors within synovial fluid that can activate the respiratory burst in our experiments. Furthermore, because they bind protein $A$, they are likely to interact with neutrophils via $\mathrm{Fc} \gamma$ receptors.

The soluble and insoluble immunoglobulin aggregates from synovial fluid of patients with rheumatoid arthritis were then separated by centrifugation. ${ }^{9}$ Activation of primed neutrophils with the soluble aggregates resulted in a chemiluminescence response which reached a maximal value by 3-4 minutes and then declined (fig 3A). However, this oxidase activity was largely absent in neutrophils which had been incubated with pronase (mean (SD) inhibition $=89 \%(16), n=6)$. Activation of primed cells with the insoluble immunoglobulin aggregates from synovial fluid resulted in a slower activation of oxidase activity which reached a maximal value by 15-20 minutes after addition (fig 3B). However, cell suspensions treated with pronase still generated substantial levels of reactive oxidants in response to these insoluble complexes (mean (SD) inhibition $=34 \%(16), \mathrm{n}=6)$ : similar values for oxidant production in pronase treated cells were obtained using these complexes at $50 \%(\mathrm{v} / \mathrm{v})$. Because FcyRII expression is not affected by pronase treatment the inhibition of oxidant production via the soluble immunoglobulin aggregates is likely to be due to the cleavage of Fc $\gamma$ RIII. Thus FcyRIII is required for mediating oxidant production in response to the soluble immunoglobulin aggregates, but this receptor plays a less important role in oxidant production stimulated by the insoluble immunoglobulin aggregates.

THE EFFECT OF BLOCKING MONOCLONAL ANTIBODIES ON NEUTROPHIL OXIDANT PRODUCTION

A more specific method for assessing the role of $\mathrm{Fc} \gamma \mathrm{R}$ receptors in neutrophil function utilised blocking monoclonal antibodies against a particular $F c \gamma R$ receptor. When the soluble immune complexes were isolated from cell free synovial fluid and used to stimulate primed neutrophils, the presence of IV3 (FcyRII) and Leu 11b (FcyRIII) inhibited the mean (SD) chemiluminescence responses by $93 \%[(13), \mathrm{n}=8]$ and $71 \%[(22), \mathrm{n}=8]$ respectively (fig 4A). Thus blocking the binding of these soluble aggregates to FcyRII completed abrogated oxidase activation. When the isolated insoluble immunoglobulin aggregates were used to stimulate primed cells, blocking with IV3 and Leu $11 \mathrm{~b}$ again resulted 

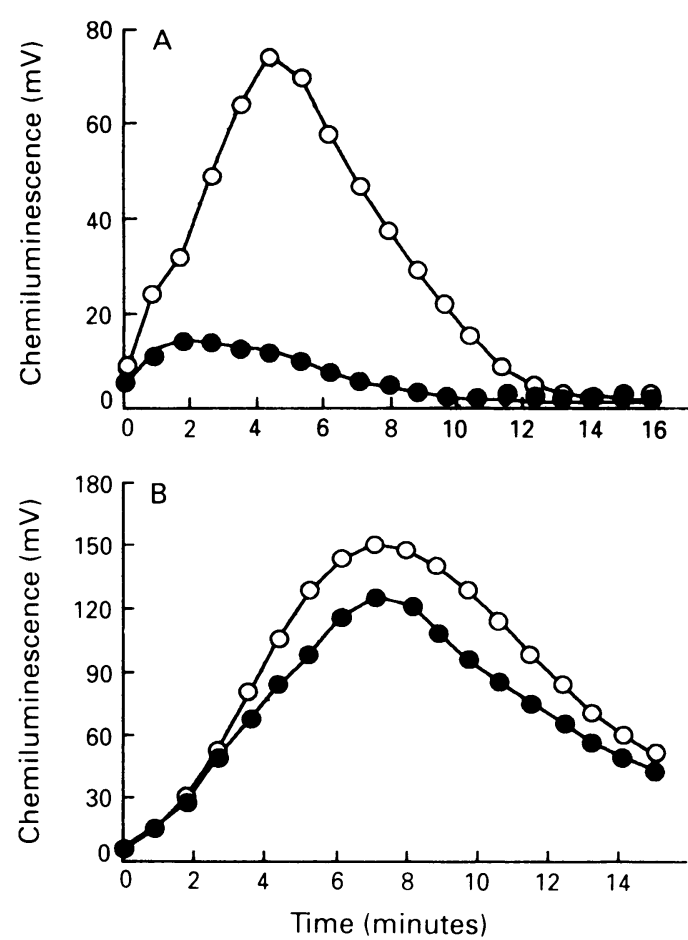

Figure 2 The effect of pronase treatment on fMet-Leu-Phe and PMA induced neutrophil chemiluminescence. Control bloodstream neutrophils in RPMI $\left(10^{7} \mathrm{cells} / \mathrm{ml}\right)$ were incubated in the presence of GM-CSF $(50 \mathrm{U} / \mathrm{ml})$ for 60 minutes at $37^{\circ} \mathrm{C}$. The primed cells were incubated for a further 30 minutes at $37^{\circ} \mathrm{C}$ in the presence (-) or absence (O) of pronase $(50 \mu \mathrm{g} / \mathrm{ml})$. At time zero, $5 \times 10^{5}$ cells were stimulated with (A) $\mu M$ FMLP or (B) $0.1 \mu \mathrm{g} / \mathrm{ml} P M A$ (final concentrations), and the chemiluminescence measured using an LKB 1251 luminometer. Both assays were performed at $37^{\circ} \mathrm{C}$ in the presence of $10 \mu \mathrm{M}$ luminol in $R P M I$ to a final volume of $1 \mathrm{ml}$. Similar results were found in at least four further experiments.

in a much lower inhibition (fig 4B). For example, when binding to Fc $\gamma$ RII was blocked, mean (SD) inhibition was only $28 \%$ [(38), $\mathrm{n}=9$ ] whilst blocking the binding to FcyRIII resulted in $40 \%$ [(17), $n=9]$. Similar results were obtained using the insoluble immune complexes at 10 or $50 \% \quad(\mathrm{v} / \mathrm{v})$ final concentration. Blocking both Fc $\gamma$ RII and III simultaneously only inhibited activation by the insoluble aggregates by $45 \%[(19), n=5]$. Doubling the concentrations of antibodies did not significantly increase the level of inhibition.

These experiments indicate that both Fc $\gamma$ RII and Fc $\gamma$ RIII are important in the activation of neutrophil oxidant production by soluble immunoglobulin aggregates. The role of these receptors in neutrophil activation by insoluble aggregates is less defined. The monoclonal antibodies used had no inhibitory effect on fMet-Leu-Phe or PMA stimulated neutrophil activation, and 197 (anti-Fc $\gamma \mathrm{RI}$ ) failed to inhibit the chemiluminescence response to fMet-Leu-Phe, PMA or soluble or insoluble immunoglobulin aggregates (data not shown).

\section{Discussion}

The combined use of depleting the neutrophils of FcyRIII by pronase treatment and the use of blocking monoclonal antibodies has shown that Fc $\gamma \mathrm{RII}$ and Fc $\gamma \mathrm{RIII}$ are both required to
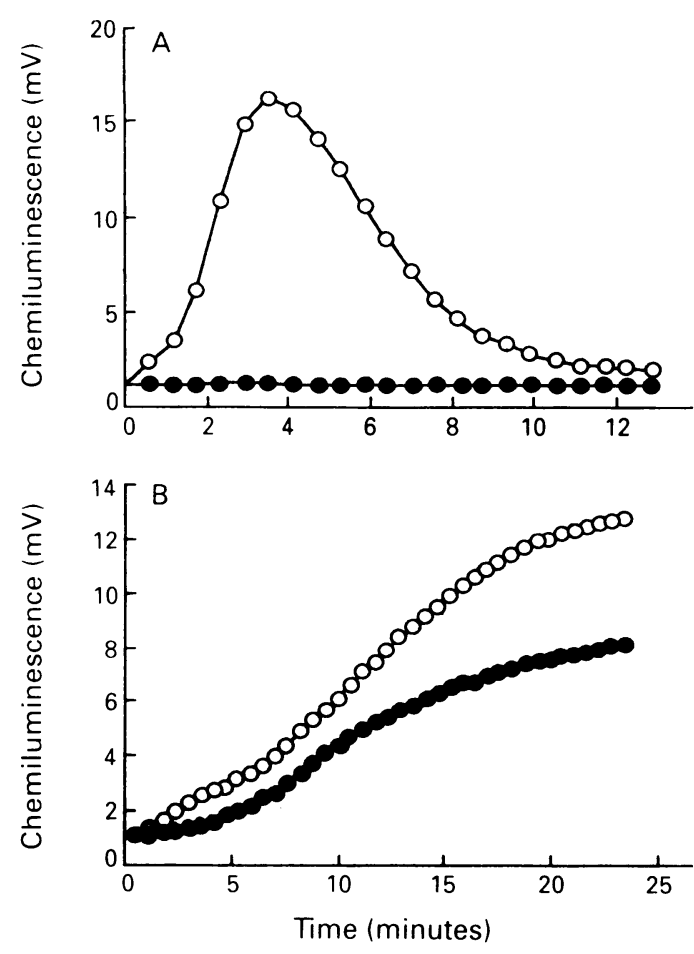

Figure 3 The effect of pronase treatment on neutrophil chemiluminescence activated by soluble and insoluble immunoglobulin aggregates from rheumatoid synovial fluid. Control bloodstream neutrophils in RPMI $\left(10^{7}\right.$ cells $\left./ \mathrm{ml}\right)$ were incubated in the presence of $G M-C S F(50 \mathrm{U} / \mathrm{ml})$ for 60 minutes at $37^{\circ} \mathrm{C}$. The primed cells were incubated for a further 30 minutes at $37^{\circ} \mathrm{C}$ in the presence (-) or absence (O) of pronase $(50 \mu \mathrm{g} / \mathrm{ml})$. At time zero, $5 \times 10^{5}$ cells were stimulated with $(A) 10 \%(v / v)$ final concentration of the supernatant of cell free synovial fluid, or (B) $10 \%(\mathrm{v} / \mathrm{v})$ final concentration of the pellet of cell free synovial fluid, and the chemiluminescence measured using an LKB 1251 luminometer. The pellet and supernatant were derived by centrifugation of the cell free synovial fluid for 2 minutes at $11600 \mathrm{~g}$. Assays were performed at $37^{\circ} \mathrm{C}$ in the presence of $10 \mu M$ luminol in RPMI to a final volume of $1 \mathrm{ml}$. Similar results were found in at least five further experiments.

varying extents for the activation of primed neutrophils by the soluble and insoluble immunoglobulin aggregates. Treatment of primed neutrophils with pronase resulted in about $80 \%$ depletion of Fc $\gamma$ RIII from the cell surface, but did not affect Fc $\gamma$ RII expression. Stimulation of cells with fMet-Leu-Phe after pronase treatment was considerably decreased (as would be predicted because 31D8 expression is closely linked to fMet-Leu-Phe responsiveness ${ }^{25} 26$ ) whereas activation by PMA was largely unaffected. This indicates that pronase treatment did not non-specifically affect neutrophil responsiveness. It is thus of great interest that pronase treatment largely abolished the ability of neutrophils to generate reactive oxidants in response to the soluble immunoglobulin aggregates isolated from the synovial fluid of patients with rheumatoid arthritis. Conversely, activation via the insoluble aggregates was inhibited to a much lower extent by pronase treatment. The use of blocking monoclonal antibodies largely confirmed the results of pronase treatment in that activation via the soluble aggregates largely requires Fc $\gamma$ RIII and Fc $\gamma$ RII. However, the use of both monoclonal antibodies together only inhibited activation by the insoluble complexes by about $50 \%$. 

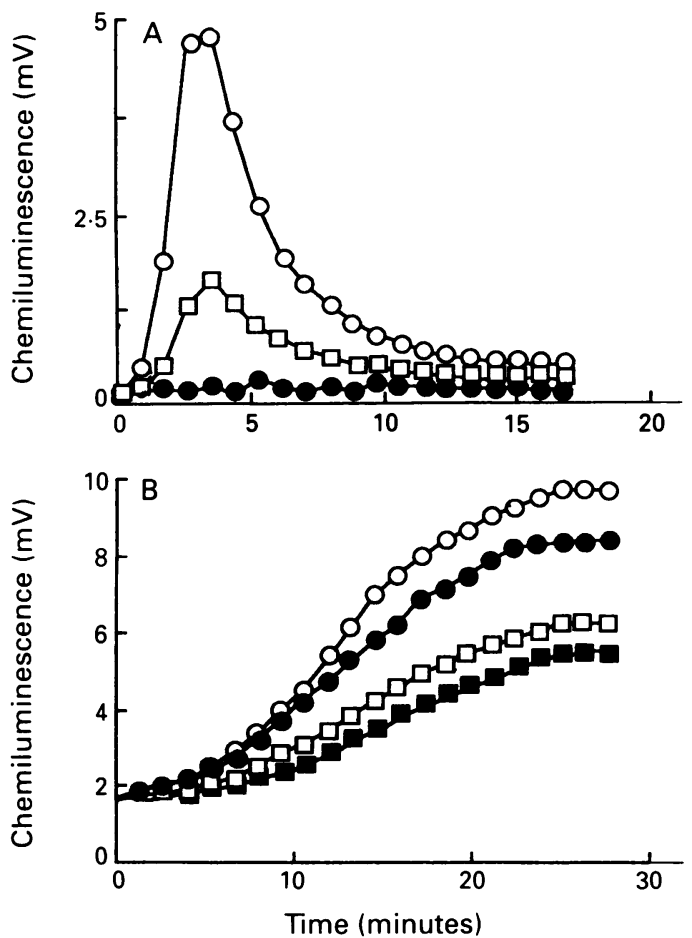

Figure 4 The effect of blocking monoclonal antibodies on neutrophil chemiluminescence activated by soluble and insoluble immunoglobulin aggregates from rheumatoid synovial fluid. Control bloodstream neutrophils in RPMI $\left(2 \times 10^{6} \mathrm{cells} / \mathrm{ml}\right)$ were incubated in the presence of $G M$ $\mathrm{CSF}(50 \mathrm{U} / \mathrm{ml})$ for 60 minutes at $37^{\circ} \mathrm{C}$. The primed cells were incubated for a further 10 minutes at $37^{\circ} \mathrm{C}$ in the absence $(O)$ or presence of Leu $11 b$ (anti-Fc $\gamma$ RIII, $\square$ ) or IV3 (anti-Fc $\gamma R I I, \bullet)$, or both antibodies together (অ). At time zero, $2 \times 10^{5}$ cells were stimulated with $(A) 10 \%$ $(v / v)$ final concentration of the supernatant of cell free synovial fluid, or (B) $10 \%(v / v)$ final concentration of the pellet of cell free synovial fluid, and the chemiluminescence measured using an LKB 1251 luminometer. The pellet and supernatant were derived by centrifugation of the cell free synovial fluid for 2 minutes at $11600 \mathrm{~g}$. Assays were performed at $37^{\circ} \mathrm{C}$ in the presence of $10 \mu \mathrm{M}$ luminol in $R P M I$ to a final volume of $1 \mathrm{ml}$. Similar results were found in at least seven further experiments.

There is much debate in previous reports regarding the role of Fc $\gamma$ RII and Fc $\gamma$ RIII in neutrophil function. On the one hand, it has been proposed that occupancy of FcyRII is required for activation of reactive oxidant production, degranulation and phagocytosis, whereas FcyRIII is only required for the binding of immune complexes without subsequent activation. ${ }^{181928}$ On the other hand, some recent evidence has suggested that both FcyRII and Fc $\gamma$ RIII are involved in activation of the respiratory burst by immune complexes. ${ }^{29}{ }^{30}$ However, if Fc $\gamma$ RIII is required for binding, then blocking occupancy of this receptor may indirectly affect the efficacy by which Fc $\gamma \mathrm{RII}$ can generate intracellular signals in response to immune complexes. Hence, Fc $\gamma$ RII and FcyRIII probably function cooperatively to bind immune complexes and generate intracellular signals which lead to cell activation. Such cooperation between these two receptors is also suggested because FcyRIII occupancy can enhance subsequent Fc $\gamma$ RII-dependent phagocytosis. ${ }^{31}$

We thank the Arthritis and Rheumatism Council, The Nuffield Foundation and Mersey Regional Health Authority for financial support.
1 Edwards S W, Hughes V, Barlow J, Bucknall R. Immunological detection of myeloperoxidase in synovial fluid from patients with rheumatoid arthritis. R. (1988). Biochem f 1988; 250: 81-5.

2 Nurcombe H L, Bucknall R C, Edwards S W. Neutrophils isolated from the synovial fluid of patients with rheumatoid arthritis: priming and activation in vivo. Ann Rheum Dis 1991; 51: 147-53.

3 Dularay B, Elson C J, Dieppe P A. Enhanced oxidative response of polymorphonuclear leukocytes from synovial fluid of patients with rheumatoid arthritis. Autoimmunity 1988; 1: 159-69.

4 Emery P, Lopez A F, Burns G F, Vadas M A. Synovial fluid neutrophils of patients with rheumatoid arthritis have membrane antigen changes that reflect activation. Ann Rheum Dis 1988; 47: 34-9.

5 Watson F, Robinson J J, Bucknall R C, Phelan M, Edwards $\mathrm{S}$ W. Receptor expression in synovial fluid neutrophils from patients with rheumatoid arthritis. Ann Rheum Dis 1993; 52: 353-9.

6 Breedveld F C, Lafeber G J M, van den Barselaar T T, van Dissel J T, Leijh P C J. Phagocytosis and intracellular killing of Staphylococcus aureus by polymorphonuclear cells from synovial fluid of patients with rheumatoid arthritis. Arthrit Rheum 1986; 29: 166-73.

7 Bender J G, Van Epps D E, Searles R, Williams R C J. Altered function of synovial fluid granulocytes in patients with acute inflammatory arthritis: evidence for activation of neutrophils and its mediation by a factor present in of neutrophils and its mediation by a factor

8 Nurcombe $\mathrm{H}$ L, Bucknall R C, Edwards S W. Activation of the myeloperoxidase- $\mathrm{H}_{2} \mathrm{O}_{2}$ system by synovial fluid from patients with rheumatoid arthritis. Ann Rheum Dis 1991; 51: 237-42.

9 Robinson J J, Watson F, Bucknall R C, Edwards S W. Activation of neutrophil reactive-oxidant production by synovial fluid from patients with inflammatory joint disease. Soluble and insoluble immunoglobulin aggregates activate different pathways in primed and unprimed cells. Biochem $\mathcal{F}$ 1992; 286: 345-51.

10 Gale R, Bertouch J V, Bradley J, Roberts-Thomson P J. Direct activation of neutrophil chemiluminescence by rheumatoid sera and synovial fluid. Ann Rheum Dis 1983; 42: $158-62$.

11 Blackburn W D J, Koopman W J, Schrohenloher R E, Heck L W. Induction of neutrophil enzyme release by rheumatoid factors: evidence for differences based on molecular characteristics. Clin Immunol Immunopathol 1986; 40: 347-55.

12 Robinson J J, Watson F, Bucknall R C, Edwards S W. Stimulation of neutrophils by insoluble immunoglobulin aggregates from synovial fluid of patients with rheumatoid aggregates from synovial fluid of patients with

13 Edwards S W. In: Duncan C J, ed. Calcium, oxygen radicals and tissue damage. Cambridge: Cambridge University Press, 1991: 35-76.

14 Kerr M A. The structure and function of human IgA. Biochem $\mathcal{F}$ 1990; 271: 285-96.

15 Fanger M W, Shen L, Graziano R F, Guyre P M Cytotoxicity mediated by human Fc receptors for IgG. Immunol Today 1989; 10: 92-9.

16 Perussia B, Dayton E T, Lazarus R, Fanning V, Trinchieri $\mathrm{G}$. Immune interferon induces the receptor for monomeric IgG, on human monocyte and myeloid cells. moxp Med 1983; 158: 1092-1113

17 Huizinga T W J, van Kemenade F, Koenderman L et al. The $40-\mathrm{kDa}$ Fc receptor (FcRII) on human neutrophils is essential for the IgG-induced respiratory burst and IgGinduced phagocytosis. F Immunol 1989; 142: 2365-9.

18 Huizinga $\mathrm{T} W \mathrm{~W}$, Kerst $\mathrm{M}$, Nuyens J H, et al. Binding characteristics of dimeric IgG subclass complexes to human neutrophils. F Immunol 1989; 142: 2359-64.

19 Tosi $M$, Berger $M$. Functional differences between the $40 \mathrm{kDa}$ and 50 to $70 \mathrm{kDa}$ IgG Fc receptors on human neutrophils revealed by elastase treatment and neutrophils revealed by elastase treatment and

20 Huizinga T W J, van der Schoot C E, Jost C, et al. The PIlinked receptor FCRIII is released on stimulation of neutrophils. Nature 1988; 333: 667-9.

21 Robinson J J, Watson F, Phelan M, Bucknall R C, Edwards $S$ W. Activation of neutrophils by soluble and insoluble immunoglobulin aggregates from synovial fluid of patients with rheumatoid arthritis. Ann Rheum Dis 1993; 52: 347-53.

22 Edwards S W, Say J E, Hart C A. Oxygen-dependent killing of Staphylococcus aureus by human neutrophils. $\mathcal{F} \mathrm{Gen}$ Microbiol 1987; 133: 3591-7.

23 Edwards S W, Holden C S, Humphreys J M, Hart C A Granulocyte-macrophage colony-stimulating factor (GM-CSF) primes the respiratory burst and stimulates protein biosynthesis in human neutrophils. FEBS Lett 1989; 256: $62-6$.

24 Edwards S W. Luminol- and lucigenin-dependent chemiluminescence of neutrophils: role of degranulation. f Clin Lab Immunol 1987; 22: 35-9.

25 Seligman B E, Melnick D A, Malech H L, Gallin J I. Identification of two subpopulations of neutrophils using the anti-neutrophil antibody $31 \mathrm{D} 8$ and correlation with functional responsiveness. F Cell Biol 1983; 97: 1580.

26 Seligmann B E, Chused T M, Gallin J I. Binding of fluoresceinated chemoattractant peptide to human neutrophils is heterogeneous and correlated with heterogeneous stimulation gell Biol 1982; 95: 21133 . 
27 Edwards S W, Watson F, MacLeod R, Davies J M. Receptor expression and oxidase activity in human neutrophils regulation by granulocyte-macrophage colony-stimulating factor and dependence upon protein biosynthesis. Biosci Rep 1990; 10: 393-401.

28 Huizinga T W J, Dolman K M, van der Linden N J M et al. Phosphatidylinositol-linked FcRIII mediates exocytosis of neutrophil granule proteins, but does not mediate initiation of the respiratory burst. $f$ Immunol 1990; 144: 1432-

29 Crockett-Torabi E, Fantone J C. Soluble and insoluble immune complexes activate human neutrophil NADPH oxidase by distinct $\mathrm{Fc} \gamma$ receptor-specific mechanisms. f Immunol 1990; 145: 3026-32.

30 Walker B A M, Hagenlocker B E, Stubbs E B J, Sandborg $R$ R, Agranoff $B$ W, Ward $P$ A. Signal transduction events and FcR engagement in human neutrophils stimulated with immune complexes. neutrophils stimulated with

31 Salmon J E, Brogle N L, Edberg J C, Kimberly R P. $\mathrm{F} C \gamma$ receptor III induces actin polymerisation in human neutrophils and primes phagocytosis mediated by Fcy receptor II. F Immumol i 991 ; 146:997-1004 